\title{
Estimating the efficiency level of different tea farming systems in Rize Province Turkey
}

\author{
Shamsheer ul $\mathrm{Haq}^{1 *}$ (D) Ismet Boz $^{1}$
}

\author{
1Department of Agricultural Economics, Ondokuz Mayıs University, 55139, Samsun, Turkey. E-mail: shamsheer213@hotmail.com. \\ ${ }^{*}$ Corresponding author.
}

ABSTRACT: The primary purpose of this study was to analyze the efficiency level of tea farms operated by owners and shareholders, and to explore the effect of different decisional, structural and management factors on efficiency. The data were collected from a stratified sample of 138 tea farmers operated in Rize province Turkey in 2017. The data envelopment analysis (DEA) program was used to estimate the efficiency scores. Tobit model was used to explore determinants of technical efficiency. Results disclosed that farmers can reduce their inputs use by $43 \%$ without compromising their yield level. However, they have low economic efficiency (0.41). Shareholder-operated farms were highly efficient (0.76) than the owner-operated farms. The factors such as old tea parcels, high land slope, and altitude were having a significant negative effect on farms' efficiency. Applying fertilizer in the root zone or mixed with soil, terracing of farmland, and performing of soil test was positively and significantly contributing to efficiency. Generally, the efficiency of tea farmers is low, and mostly farm management and structure related factors were negatively affecting the farmer's efficiency. The farmers should be aware of associated benefits with early replanting tea, fertilizer application in the root zone and terracing to control their production cost.

Key words: tea farming, technical efficiency, economic efficiency, owners, shareholders.

Estimando o nível de eficiência de diferentes sistemas de cultivo de chás na província de Rize na Turquia

RESUMO: O estudo analisa o nível de eficiência de dois sistemas agrícolas diferentes, tais como proprietários e fazendas de chá operadas por acionistas, bem como explorar o efeito de diferentes fatores de decisão, estruturais e de gestão na eficiência. Total de 138 produtores de chá foram selecionados através do procedimento de amostragem estratificada na provincia de Rize. Os resultados revelaram que os agricultores podem reduzir o uso de insumos em 43\% sem comprometer seu nível de produção. No entanto, eles têm baixa eficiência econômica (0,41). As fazendas operadas pelos acionistas eram altamente eficientes $(0,76)$ do que as fazendas operadas pelos proprietários. Os fatores como antigas parcelas de chá, alta inclinação de terra e altitude estavam tendo um efeito negativo significativo sobre a eficiência das fazendas. A aplicação de fertilizantes na zona das raizes ou misturados com o solo, o terraceamento de terras agricolas e a realização de testes de solo contribuíram de forma positiva e significativa para a eficiência. Geralmente, a eficiência dos produtores de chá é baixa, e principalmente os fatores relacionados à gestão e estrutura da fazenda afetavam negativamente a eficiência do agricultor. Os agricultores devem estar cientes dos beneficios associados ao replantio precoce do chá, aplicação de fertilizantes na zona de raízes, terraços para controlar seu custo de produção. Palavras-chave: cultivo de chás, eficiência técnica, eficiência econômica, proprietários, acionistas.

\section{INTRODUCTION}

Worldwide, tea is the second most consumed and enjoyed drink. It has medicinal properties so can be used for the treatment of various human diseases (KHAN \& MUKHTAR, 2013). Tea is cultivated as a perennial crop in many countries across the world such as China, India, Kenya, and Sri Lanka. Turkey is the fifth largest tea growing country in the world (WORLD ATLAS, 2016). The Rize Province on the eastern Black Sea coast, which has mountainous topography and climate suitability (UL HAQ \& BOZ, 2018), is the main tea producing area in Turkey; $90 \%$ of the area in the Rize Province is under tea farming, accounting for $78 \%$ of the country's total tea production (RTB, 2014). In this province, tea enterprise is a huge source of income for more than 200,000 families who are involved in owner-operated or shareholder tea farming, or are employees in a tea factory (AYLANGAN, 2011).

A manager's efficiency in using fewer inputs to produce more output is of paramount importance for a successful business (SIDDIQUE, 2014). Therefore, it is crucial to study and measure a manager's efficiency in such businesses. However, most of the studies conducted around the world have focused on the technical efficiency (TE) of a manager in all disciplines, including agriculture. In agriculture, many efficiency studies have focused on crop yield 
and livestock efficiency using production function, mathematical programming with panel, crosssectional and aggregate data, and parametric and non-parametric frontier function (TZOUVELEKAS et al., 2001; SARAFIDIS, 2002; HELFAND, 2004; IRÁIZOZ et al., 2003; KYEI et al., 2011; AISYAH et al., 2012; KALANGI et al., 2014; KARANIGICHIMU et al., 2015; HAQ et al., 2016; ABDULRAHMAN, 2016; HAQ et al., 2017). Many studies in Turkey have also addressed the efficiency of farmers for production of different crops (ABAY et al., 2004, CINEMRE et al., 2006, BOZOĞLU \& CEYHAN, 2008, BAYRAMOGLU \& GUNDOGMUS, 2008, KILIC et al., 2009, BOZOĞLU \& CEYHAN, 2009, DEMIRCAN et al. 2010 and ALEMDAR et al., 2010). Locally and globally, all studies have emphasized on the efficiency of farmers related to different crops, livestock, and fisheries, which sheds light on the fact that it is an important concept that needs to be empirical for enjoying long-term business profitability. In addition, efficiency is an important indicator that is being used as a sustainability measure in agriculture (ZAHM et al., 2008, HANI et al., 2006, GAFSI \& FAVREAU, 2010, JOLLANDS et al., 2004, HAQ \& BOZ, 2017).

In the review of the literature, no studies were found to be conducted earlier evaluating the efficiency of tea farmers in Turkey. Although, Turkey is one of the largest tea producers and exporters, production-related problems still hinder the progress of the sector. The most common production-related problems include aging, contraction of land over generations, illegal tea entry, delaying of renewal tea plants, fluctuation in the tea industry, high cultivation, cost and scarce organic tea (ÖZCAN \& YAZICIOĞLU, 2013). Land fragmentation, low tea prices, late payment, and deficiency of cohesion in organizations are some of the problems faced by small-scale farmers (SAKLI, 2011). Although, the state-owned firm has control over the price and marketing of tea, an increasing number of private firms also play a role in the tea enterprise, affecting the earnings of the tea farming community. Furthermore, the emerging land shareholding farming system in tea production cannot be ignored in the development of tea enterprise. Therefore, for sustainable tea farming, it is necessary to bridge this efficiency estimation gap.

Shareholder-operated farms (SHFs) are those farms ,which have been given the right of using the land by the real owner who cannot do the farming due to specific reasons. In general, the real owner has his own occupation or may have migrated to another city. In his absence, the SHFs cultivate tea on a shared basis. An SHFs does not have his own land.
The cultivation expenses and returns from the tea crops are shared on an equal basis between the real owner of land and SHFs. Exerting pressure on the SHF may affect their efficiency level. Compared to an owner-operated farms (OOFs), the equal sharing of returns may pressurize SHFs to use more inputs, including technical inputs. This assumption regarding SHFs is necessary to clarify their efficiency in tea production in comparison with OOFs. This study was aimed to analyze the efficiency level of tea farmers and exploring the efficiency level of SHFs and OOFs. Consequently, this study also fulfills the research gap of tea farms efficiency. The primary objective was to analyze the tea farmers' efficiency level and examine the difference in efficiency of both types of farm. The secondary objective was to explore the determinants of TE by constructing an econometric model.

\section{MATERIALS AND METHODS}

\section{Study area and sample size}

The selection of the study area plays a vital role in any research study depending on the research problem. Socioeconomic conditions of the farmers in the Rize Province are largely dependent on tea production. Therefore, the Rize Province was selected as the study area. The Rize Province is situated between Trabzon and Artvin on the eastern Black Sea coast and has a total area of 3,920 $\mathrm{km}^{2}$. The accessible population for this study was defined by employing a similar method explained by BOZ \& AKBAY (2005) and BOZ (2015). A well-designed questionnaire was used to collect data from 138 tea growers from the Rize Province. The following three main tea producing districts were selected: Rize Merkez, Pazar, and Ardeşen. The target population was the farmers who were involved in tea farming in these three districts. A list of predetermined villages from each district was obtained from the district agricultural offices. The selection criteria for villages were potential for tea farming, location, population density, and the extent to which they represent the socioeconomic characteristics of rural life in the region. The optimal size of the sample was determined by using the stratified sampling technique proposed by YAMANE (2001). The sampling formula is given below.

$$
n=\frac{N \sum N_{h} S_{h}^{2}}{N^{2} D^{2}+\sum N_{h} S_{h}^{2}}, D^{2}=\frac{e^{2}}{t^{2}}
$$

Where in equation $1 ; \mathrm{n}$ denotes samples size required, $\mathrm{N}$ shows accessible population of tea growers. 
$\mathrm{n}=$ sample Size. $N_{h}$ means number of tea growers in each stratum, $S_{h}$ describes the standard deviation within each stratum, $D^{2}$ explains the expected variance, e denotes accepted error from mean and $t$ is the $t$ value of corresponding the accepted confidence interval. By accepting 3\% error from the mean (e) with $95 \%$ confidence interval $(t=1.645)$, the minimum sample size was calculated as 138 . This number was proportionately distributed among all the strata. From each stratum, farmers were randomly selected for an interview to collect data. This method of sampling was used by UL HAQ and BOZ (2019) in similar way in a study conducted in Rize province.

\section{Efficiency model}

The two models were constructed in this study. In the first stage, efficiency scores were estimated, and in the second stage, the determinants responsible for changes in the efficiency of a farmer were assessed. In the first model, efficiency scores were estimated by data envelopment analysis. In the second model, the Tobit model was run using TE scores as dependent variables. The following two components of efficiency proposed by FARRELL (1957) were used: TE and allocative efficiency (AE). Since tea farmers have control over the inputs compared to the output, an input-oriented efficiency model was constructed to estimate the efficiency score of SHFs and OOFs. TE and AE gave the economic efficiency (EE). TE is defined in many ways. In this study, TE was defined as the farmer's ability to use minimal inputs to reach the given output level. $\mathrm{AE}$ is defined as "the ability to use inputs in their optimal proportions at a given price and technology" (FARRELL, 1957).

The efficiency model was defined according to suggestions provided by CHARNES et al., (1978) and BANKER et al., (1984). The tea output per decare $(\mathrm{kg} / \mathrm{Da} ; 10 \mathrm{Da}=1$ Hectare $)$ was used as output in the model $\left(\mathrm{y}_{\mathrm{i}}\right)$. Labor for 1 decare (working days) and fertilizer quantity $(\mathrm{kg} / \mathrm{Da})$ were used as inputs. The input (Labor and fertilizer quantity) matrix is denoted as $\mathrm{K} \times \mathrm{N}$ and the output matrix is denoted as $\mathrm{M} \times \mathrm{N}$. The efficiency model for the estimation of efficiency scores of SHFs and OOFs is presented below.

Minimize $_{\theta, \lambda} \theta$

Subject to $-\mathrm{y}_{\mathrm{i}}+\mathrm{Y} \boldsymbol{\lambda} \geq 0$

$\theta x_{i}-X \lambda \geq 0$

$\lambda \geq 0$
Where in Eq 2; $\theta=\mathrm{TE}$ score and $\lambda=\mathrm{N} \times$ 1 vector of weights that define the linear combination of the peers of the $i^{\text {th }}$ farmer. The model for EE is computed as follows:

Minimize $\lambda x_{i} w_{i}^{\prime} x_{i}^{*}$

Subject to $-\mathrm{y}_{\mathrm{i}}+\mathrm{Y} \lambda \geq 0$

$x_{i}^{*}-X \lambda \geq 0$

$\lambda \geq 0$

In equation $3 ; w_{i}^{\prime}=$ transpose of vector of input prices and $x_{i}^{*}=$ cost minimizing vector of input quantities for the $i^{\text {th }}$ farmer. Both of the above mentioned functions are subjected to a constant return to scale (CRS), demonstrating that the input and output increased in same proportion. The $\mathrm{EE}_{\mathrm{CRS}}$ of the $i^{\text {th }}$ farmer was estimated as follows:

$E E_{i, C R S}=w_{i}^{\prime} x_{i}^{*} / w^{\prime} x_{i}$

$\mathrm{EE}_{\mathrm{i}, \mathrm{CRS}}$ in equation 4 represents the minimum cost and observed cost ratio when the price and technology at the farm are given (COELLI et al., 2005). The CRS condition cannot be assumed to be adequate in this scenario; hence, the efficiency model was modified into a variable return to scale (VRS) by adding the convexity constraint $\mathrm{N} 1 \lambda=1$. In this case, $\mathrm{N} 1$ shows $\mathrm{N} \times 1$ vector of ones and $\boldsymbol{\lambda}$ is an $\mathrm{N} \times 1$ vector of constant of the first model mentioned above. Due to the addition of a convexity constraint, TE is decomposed into pure technical efficiency (PTE), which reflects the farmer's capability to produce at an optimal scale and scale efficiency (SE) that represents the skill of a farmer to choose the optimal level of inputs that will produce the expected level of output (KUMAR \& GULATI, 2008). SE is equal to the ratio between $\mathrm{TE}_{\mathrm{CRS}}$ and $\mathrm{TE}_{\mathrm{VRS}}$ scores. If $\mathrm{SE}=1, \mathrm{TE}_{\mathrm{CRS}}$ will be the same as $\mathrm{TE}_{\mathrm{VRS}}$, which indicated that the farmers are supposed to be efficient. The comparison of SHFs and OOFs based on scale inefficiency was determined by comparing their efficiency scores under the non-increasing return to scale (NIRS) with $\mathrm{TE}_{\mathrm{CRS}}$ scores. When $\mathrm{SE}<1$ and $\mathrm{TE}_{\mathrm{NIRS}}=\mathrm{TE}_{\mathrm{CRS}}$, the farmer will be scaled to be inefficient due to the increasing return to the scale. When $\mathrm{Se}<1$ and $\mathrm{TE}_{\mathrm{NIRS}}>\mathrm{TE}_{\mathrm{CRS}}$, the farmer will be scaled to be inefficient under the decreasing return to the scale. The $\mathrm{AE}$ is expressed as follows in equation 5:

$A E_{i}=E E_{i, V R S} / T E_{i}$

\subsection{Determinants of Technical Efficiency in Tea Farming}

The Tobit model was used to examine the determinants of TE. The Tobit model allows for constructing a linear relationship between the 
independent and dependent variables when the dependent variable is either left or right centered. TE scores were used as dependent variables to show the relationship between management and socioeconomic independent variables. As the dependent variable (TE score) is a censored variable which has lower limit (0) and upper limit (1). Therefore, the current dependent variable is constrained in some way. In this case, LONG (1997) described the applicability of double censored Tobit model. The alternative approaches such as OLS regression give the inconsistent, ineffective, and biased estimates because it reduces the true effect of parameter by reducing the slope (GUJARATI, 2003). BRAVO-URETA et al. (2007); NYAGAKA et al. (2010); ALAM, (2011); KALIBA et al., (2007); CINEMRE et al., (2006) also used the Tobit model in their studies at second stage to explore the determinants of the efficiency.

Before, running the Tobit model, the multicollinearity was checked by VIF values. The VIF value of one independent variable with respect to the all other variables were not more than 2 . For example, the VIF values of farmer age with all other independent variables was in range of 1 to 2. Similarly, step by step VIF values for all the independent variables were estimated and analyzed. The accepted value of VIF should not be greater than 4 was set as a criterion of analyzing the assumption of multicollinearity in the current study. The literature described different threshold value of VIF describing no multicollinearity among independent variables. Results described no multicollinearity exists among all the independent variables. O'BRIEN (2007) recommended the maximum value of VIF to be 5, and PAN and JACKSON (2008) recommended the acceptable threshold VIF value of 4 . The STATA program was used for Tobit model. The specific form of the Tobit Model is given below.

TE Score $=\beta_{0}+\beta_{1} x_{1}+\beta_{2} x_{2}+\beta_{3} x_{3}+\beta_{4} x_{4}+\beta_{5} x_{5}+\beta_{6} x_{6}$ $+\beta_{7} x_{7}+\beta_{8} x_{8}+\beta_{9} D_{1}+\beta_{10} D_{2}+\beta_{11} D_{3}+\beta_{12} D_{4}+\beta_{13} D_{5}$ $+\beta_{14} D_{6}$

Equation 6 shows the independent variables those presented below as described in table1.

\section{RESULTS AND DISCUSSION}

\section{Efficiency level of the farmers}

The minimum, maximum and mean of different types of efficiencies were presented in table 2. Farmers having efficiency scores less than 1 were categorized as inefficient farmers. As shown in table 2 , the tea farmers were reported to have $57 \%$ TE, suggesting that they can reduce their input quantity by $43 \%$ [ i.e. $\left.=1-(0.57 / 1)^{*} 100\right]$ without compromising the current level of tea yield. Moreover, it can be stated that only $57 \%$ of potential tea output was obtained by the tea growers with the given mix of inputs. It means that the shortfall of observed output is the result of inefficient use of the inputs that were

Table 1 - Definitions of independent variables and their expected signs.

\begin{tabular}{|c|c|c|c|}
\hline variable & Definition & Units/Scores & Hypothesis \\
\hline $\mathrm{X}_{1}$ & age of farmer & year & - \\
\hline $\mathrm{X}_{2}$ & education of farmer & year & + \\
\hline $\mathrm{X}_{3}$ & family members & number & + \\
\hline $\mathrm{X}_{4}$ & land under tea & decare & $-/+$ \\
\hline $\mathrm{X}_{5}$ & parcel & number & - \\
\hline $\mathrm{X}_{6}$ & age of tea parcel & year & - \\
\hline $\mathrm{X}_{7}$ & slope & $\%$ & $-/+$ \\
\hline $\mathrm{X}_{8}$ & altitude & meter & $-/+$ \\
\hline $\mathrm{D}_{1}$ & soil test performance & $1=$ yes $; 0=$ otherwise & + \\
\hline $\mathrm{D}_{2}$ & fertilizer application method & 1 for applying in root zone or mixed with soil, otherwise 0 ) & + \\
\hline $\mathrm{D}_{3}$ & erosion risk & $1=$ yes; $0=$ otherwise & - \\
\hline $\mathrm{D}_{4}$ & terrace status & $1=$ yes $; 0=$ otherwise & + \\
\hline $\mathrm{D}_{5}$ & cooperative membership & $1=$ yes $; 0=$ otherwise & + \\
\hline $\mathrm{D}_{6}$ & farming type & 1 for shareholder-operated farm, otherwise 0 ) & $-/+$ \\
\hline
\end{tabular}

Ciência Rural, v.49, n.12, 2019. 
Table 2 - The efficiency scores of tea farmers in Rize Province.

\begin{tabular}{lcccrr}
\hline Efficiency & Minimum & Maximum & Mean & \multicolumn{2}{c}{ Std. Deviation } \\
\hline TE & 0.16 & 1.00 & 0.57 & 0.23 & 40.35 \\
AE & 0.22 & 1.00 & 0.71 & 0.21 & 29.57 \\
EE & 0.12 & 1.00 & 0.41 & 0.23 & 0.23 \\
PTE & 0.09 & 1.00 & 0.52 & 0.10 & 46.09 \\
SE & 0.54 & 1.00 & 0.90 & 11.11 \\
\hline
\end{tabular}

CV denotes coefficient of variation.

in the control of tea farmers. The most technically inefficient farmers who had an average score of $0.16 \mathrm{TE}$ can reduce the inputs by $84 \%$ [ i.e. $=$ $\left.1-(0.16 / 1)^{*} 100\right]$ to achieve the TE level of its most efficient counterpart. The pure technical efficiency (PTE) was relatively low as compared to the scale efficiency (SE). Therefore, the main cause of low TE of tea farmers is PTE, which addresses the problem of unskilled tea farmers. They need some technical education regarding tea production.

The Allocative efficiency score was in range of 0.22 to 1.00 , with an average of 0.71 . This implies that the allocative efficiency level of tea growers was relatively high as compared to the technical efficiency. It means the tea growers were better in using the low-cost combinations of the inputs. The combine effect of $\mathrm{AE}$ and TE describes the $\mathrm{EE}$ of tea growers which ranges from 0.12 to 1.00 with an average of 0.41 . This means that if the sampled tea farmers (on the average) were to reach the EE level of the most efficient tea grower, then they could reduce their expenses by $>50 \%$ [i.e. $=$ $\left.1-(0.41 / 1)^{*} 100\right]$. Similarly, if the most inefficient tea farmer were to reach the efficient level in EE, then he could experience the cost saving by $88 \%$ [i.e. $=$ $1-(0.12 / 1) * 100]$. The low EE level of the tea growers was due to the low TE of the farmers. This means the tea growers could improve their EE efficiency level, if they used the farm inputs technically efficient, because among tea growers in locality, the technical inefficiencies constitute more serious problems as compared to allocative efficiency.

\section{Summary of return to scale of sampled farmers}

In addition to analyzing the extent of efficiencies of the tea growers, it is also very important to analyze the distribution of tea growers to fall in the three stages of production frontier. For example, how many tea growers fell at the decreasing, constant, and increasing return to scale groups. As shown in table 3, a high percentage of farmers $(66.67 \%)$ were operating at increasing the return to scale (IRS), suggesting that the tea output is increasing by more than the proportional change in inputs (labor and fertilizer). It means that most of the tea growers were operating in suboptimal region of the production frontier. Only $6.52 \%$ of the farmers are producing tea at CRS, indicating that the tea output is proportionally increasing with the increasing tea inputs. The remaining farmers were operating at decreasing return to scale. Their tea output increases by less than the proportional change in inputs. Since $37 \%$ of tea growers were operating over superoptimal region of the production frontier, it described

Table 3 - Summary of return to scale of sampled farmers.

\begin{tabular}{lcccc}
\hline Return to Scale & Frequency & Percent & Valid Percent & Cumulative Percentage \\
\hline CRS & 9.00 & 6.52 & 6.52 & 6.52 \\
DRS & 37.00 & 26.81 & 26.81 & 33.33 \\
IRS & 92.00 & 66.67 & 66.67 & 100.00 \\
\hline
\end{tabular}

Ciência Rural, v.49, n.12, 2019. 
the situation of tea farmers working above the optimal scale of production.

\section{Frequency and percentage of farmers}

Table 4 represents the frequency and percentage of farmers in both framing systems. According to the survey, $20 \%$ of the sampled farmers were SHFs and $80 \%$ were OOFs.

\section{Efficiency Score of Shareholder Farms and Owner- Operated Farms}

Table 5 shows the efficiency level of shareholder and owner-operated farms. The shareholder-operated farms were reported to be technically more efficient than owner-operated farms. Their TE score was 0.76 , indicating that they could still reduce their input quantity without compromising the tea yield level. If they control their input use in proportion to the output, they can enjoy a good share of income. This good efficiency level in comparison to that of OOFs, may be due to their share in the cost and income on an equal basis. Hence, SHFs are attentively using their input to reduce the volume of production cost and obtaining good yield level, which in return gives a good proportion of total income. Conversely, OOFs can reduce their inputs by $47 \%$. SHFs can reduce their cost by $40 \%$, while OOFs can reduce their production cost by $64 \%$. The main cause of poor TE of OOFs is PTE, which explains their poor skills. The OOFs need to significantly improve their personal skills in tea production to increase their efficiency level. The SHFs are also allocative and economically efficient as compared to OOFs. Many studies have reported that farmers who rent their land are more efficient than those who do not rent. Renting the land facilitates the transfer of land from less productive households to more productive ones. It also reduces the marginal product of the land among households having different land and labor endowments (DEININGER \& JIN, 2005; YAO, 2007; ZHANG et al., 2011; DEININGER et al., 2014; WANG et al., 2015).

\section{Description of the independent variables}

The managerial capacity has often been represented by some aspects such as age, and education when authors has concern of exploring the efficiency differences between the agricultural productions (COELLI et al., 2002; UL HAQ et al., 2017). LI and SICULAR (2013) stated that the technical efficiency reaches its maximum level when the average age of the family labor force is 45 years, afterward it starts to decline. Similarly, further review of literature also describes the possible negative effect of age of farm managers on technical efficiency (LAMBARRAA et al., 2006; HANSSON, 2008). They said that the young farm managers are more likely to adopt the new technologies and to apply the changes in crop management with the passage of time, which contribute in technical efficiency positively. Therefore, the age of the farm manger was expected to have negative effect on the technical efficiency.

The second variable of managerial capacity was education, and it was hypothesized to have positive effect on the technical efficiency. More educated farmers can get the assistance from various source of information. Therefore, education may influence the ability of farmer to understand, interpret, respond, and adopt the available new farm technologies faster, which contribute to technical efficiency positively (POUNGCHOMPU \& CHANTANOP, 2015; DESSALE, 2019) .

The household size was described in form of family members. The positive effect of family members on technical efficiency was expected due to the possibility of family members to work on their farm. Hence, they are more likely to use the farm inputs efficiently (ILIYASU et al., 2016). The land under tea was expected to have positive or negative effect on the technical efficiency in tea production. As land size increases, it may enable the farmers to adopt the new technologies which lead to scale of economies situation, in this way the land size under crop can contribute positively in efficiency. BHATT \& BHATT (2014) stated that the technical efficiency decreases with a certain level of farm size,

Table 4 - Frequency and percentage of shareholders and owners.

\begin{tabular}{lcc}
\hline Farmer's Categories & Frequency & Percentage \\
\hline Owner-operated farms & 111 & 80 \\
Shareholder-operated farms & 27 & 20 \\
\hline
\end{tabular}

Ciência Rural, v.49, n.12, 2019. 
Table 5 - Efficiency level of shareholder and owned farmers.

\begin{tabular}{|c|c|c|c|c|c|}
\hline \multirow[t]{2}{*}{ Efficiency } & \multicolumn{2}{|c|}{------Owned Land Farmers (OOFs)------ } & \multicolumn{2}{|c|}{----------Shareholders Farmers (SHFs)--------- } & \multirow[t]{2}{*}{ p-Value } \\
\hline & Mean & Std. Deviation & Mean & Std. Deviation & \\
\hline $\mathrm{TE}$ & 0.53 & 0.21 & 0.76 & 0.21 & 0.00 \\
\hline $\mathrm{AE}$ & 0.70 & 0.20 & 0.78 & 0.24 & 0.08 \\
\hline $\mathrm{EE}$ & 0.36 & 0.19 & 0.60 & 0.27 & 0.00 \\
\hline PTE & 0.48 & 0.21 & 0.67 & 0.23 & 0.00 \\
\hline SE & 0.90 & 0.09 & 0.87 & 0.14 & 0.11 \\
\hline
\end{tabular}

after that it tends to increase, due to the decline in production cost and rise in farm income. Conversely, the farm managerial ability can decrease with given technology with large size of land, which contribute negatively to technical efficiency (DESSALE, 2019).

The size and number of scattered parcels affect agriculture in order to technology adoption and efficient use of labor and other farm inputs. ATANASOVA TODOROVA, \& LULCHEVA (2005) stated the small size parcel and large number of scattered parcels of land negatively affect the farm production. They said that the increase in size, and decrease in number of parcel would enhance the farm productivity as well as farm income. They also reported that the number of parcels affects the plan of land operation. The negative effect of number of parcels on technical efficiency was hypothesized. Similarly, the age of tea parcel was expected to have negative effect on technical efficiency. The aged tea parcel requires more fertilizer input and also gives low yield of crop. TREDER et al (2010) and MIKA et al. (2002) described the negative effect of plant aging on crop productivity.

The tea crop is very sensitive to climate and required no stagnation of water. Moreover, land with different altitude and slope of land differs in soil type, availability of sunlight, pressure of wind, accessibility of water and crop productivity. Different altitude and slope also may affect the management of crop (BEGUM et al. 2010; GHOSH et al., 2014). Therefore, the effect of slope and altitude on technical efficiency was unclear, and they were hypothesized to have positive or negative effect on efficiency. The performance of soil test was expected to have positive effect on technical efficiency. The farmer who performed the soil test is able to apply the farm inputs in suitable quantity according the requirements of soil which can increase the efficiency level. Similarly, fertilizer application methods were expected to have positive contribution to technical efficiency. The fertilizer application at root zone or by mixing with soil lower the fertilizer quantity and increase its effect on crop productivity. Soil erosion increase the loss of nutrients required by the tea plant, and also increase the chance of leaching of fertilizer to water streams. This can hinder the farmer to be technical efficient. Therefore, it was hypothesized to have negative effect on efficiency.

Since terracing makes the farm practice easy to be executed at farm over the mountains in locality, it was expected to have positive effect on efficiency. Cooperative membership is also expected to have positive effect on efficiency, because it makes it possible for farmers to have more influence on prices when marketing their products as well as purchasing their inputs. The farming type was expected to have positive or negative effect on efficiency since there are different statements available in the literature regarding different farming types. SOULE et al., (2000) stated that the share-renters and cash-renters were less likely to adopt farm practices having long term benefits. Conversely, PLACE and OTSUKA (2002) indicated that the different land tenure systems have no impact on crop productivity.

\section{Determinants of Technical Efficiency}

The determinants of TE were explored by the Tobit model (Table 6). All coefficient signs were according to the expectations. Negative association of independent variables such as parcel number, parcel age, slope, altitude, and erosion risk was explored. The positive increase in these variables negatively affects the TE of farmers in tea technical efficiency. Parcel age, land slope, altitude, and erosion risk have a significant negative effect on efficiency of tea growers. Degree of efficiency is positively associated with the farmers' age and education level, the number of family members, land under tea, soil 
Table 6 - Determinants of Technical Efficiency.

\begin{tabular}{|c|c|c|c|c|}
\hline Parameters & Coefficient & Std. Error & t-value & p-value \\
\hline Constant & 0.579 & 0.105 & 5.540 & $0.000^{*}$ \\
\hline Age & 0.0002 & 0.001 & 0.160 & 0.875 \\
\hline Education & 0.001 & 0.003 & 0.430 & 0.670 \\
\hline Family members & 0.006 & 0.007 & 0.870 & 0.385 \\
\hline Land under tea & 0.002 & 0.002 & 0.790 & 0.429 \\
\hline Parcel & -0.005 & 0.004 & -1.320 & 0.190 \\
\hline Age of parcel & -0.003 & 0.001 & -4.130 & $0.000^{*}$ \\
\hline Slope & -0.002 & 0.001 & -2.600 & $0.010^{*}$ \\
\hline Altitude & -0.00013 & 0.00004 & -3.000 & $0.003^{*}$ \\
\hline Soil test performance & 0.102 & 0.031 & 3.280 & $0.001^{*}$ \\
\hline Fertilizer application method & 0.059 & 0.026 & 2.300 & $0.023^{*}$ \\
\hline Erosion risk & -0.087 & 0.027 & -3.190 & $0.002^{*}$ \\
\hline Terrace status & 0.139 & 0.032 & 4.350 & $0.000^{*}$ \\
\hline Cooperative membership & 0.051 & 0.034 & 1.520 & 0.132 \\
\hline Framing type & 0.137 & 0.035 & 3.910 & $0.000^{*}$ \\
\hline
\end{tabular}

Log Likelihood $=64.77 ;$ LR $\chi^{2}=169.09 ; p$-value $=0.00$. The significance level is ${ }^{*}$ at $5 \%$.

test performance, fertilizer application method, terrace status, and the membership of cooperative and farming type. Education of family members and land under tea has no significant effect on efficiency. If fertilizers are applied in root zone or mixed in the soil, it will have a significantly positive result on efficiency. Terrace formation in a tea orchard also has a significant effect on efficiency, making the orchard management easy. The last independent variable farming type explains that shareholding has a positive association with efficiency. These results are similar to those reported by FENG (2008), which indicated that rice farmers who had rented the land achieved the higher TE than those who did not rent the land. It implies that the efficiency of farmers increases when they rent land on cash or on a shared basis. A land may be leased if the owner of land is not living in the study area due to other occupation and they give their land on a shared basis, which divides the cost and income equally between the owner of land and shareholder. This enables the shareholder to manage tea farming in an optimum way to control the input and obtain a good yield. HONG and YABE (2015a) reported similar effect of farmer's age, and education as analyzed in current study, but opposite effect was described in terms of the age of tea orchard, and slope of tea land on TE, while the family size has a negative impact. They also explained that the cooperative participation also has significant positive effect on efficiency. Similarly, HONG and YABE (2015b), in another study, described negative effect of farmer's age, education, and cooperative participation on TE, while positive effect of tea age and household size on efficiency of tea growers. In addition, HAZARIKA and SUBRAMANIAN (1999) explained the negative impacts of age of tea orchards or trees on efficiency as explored by the current study in regard of age of tea orchard. BASNAYAKE \& GUNARATNE (2011) shed light on the negative impact of age and education of farmers on the efficiency level in tea production, when they applied the inefficiency Cobb Douglas model. When the Trans log model was applied, a positive association of age and education were reported. SAIGENJI and ZELLER (2009) elucidated that opposite result regarding the number of tea plots and age of orchard have a positive impact on efficiency. 


\section{CONCLUSION}

The overall efficiency in tea production of the sampled farmers was very poor, with an average score of 0.57 . They can reduce their input quantity by $43 \%$ without compromising their crop yield level. Similarly, they were bearing high cost of tea cultivation by $59 \%$. The poor TE level of tea farmers was caused by pure PTE, which was associated with the farmer's personal skills. Most of the sampled farmers $(66.67 \%)$ were operating in suboptimal region of production frontier. It described the situation of increasing return to scale which explains that these tea growers were operating at the points exist before the optimal point over the production possibility curve. Similarly, $37 \%$ tea growers were operating at decreasing return to scale which fell at the superoptimal region of production possibility curve.

SHFs were more efficient than OOFs. SHFs are attentively using their input to control the cost and earn a high income, which would be equally divided between real owner of land and them. The low efficiency level of OOFs was due to their very poor PTE which described that OOFs should improve their personal technical skills. They should control their inputs by using them technically in good combination. Both types of the farmers were almost the same in SE.

A significant effect of many variables related to the management (Terracing, soil test performance, and fertilizer application methods) and farm structure (Soil erosion problem, high slope and altitude, old tea orchard or parcels) for the determination of efficiency was found. All these variables describe that the tea growers should improve their farm structure because most of the determinants of tea growers' efficiency were related to farm structure. For example, the slope and altitude, parcel numbers etc. are directly related to farm structure. As it was explained earlier, tea farmers should improve their personal skills to be technically efficient. Because it was also evident from the determinants regarding their skills such as fertilizer application methods, terracing and soil test performance which affected their efficiency significantly.

Briefly, the farmers should increase their efficiency by focusing on basic management practice. They should also apply fertilizers according to the recommended amount per decare. Highly sloped land should be converted into a terrace for tea plantation, which has a positive impact on the efficiency, and makes the management of tea easy. The farmers those who have other occupation and cannot do farming, and those who do not live in the region should lease their land on a share basis. This practice is positively affecting the efficiency, and ensures the continuity of tea farming in the study area. It is highly recommended that training programs should be held in the study area focussing on tea production technology to increase the efficiency. Training should emphasize the associated benefits of fertilizer application method (mixing with soil and applying at root zone), and performing terracing when land has high altitude and slope. In doing so, the farmers will be able to reduce production cost, ultimately affecting the final consumer and increasing social welfare.

Review of related literature showed that there was no earlier study regarding the technical efficiency of tea framers. Therefore, this study fulfills the research gap of evaluating the efficiency of different land tenure forms in tea farming in Turkey. Results explained that the tea framers who want to leave tea farming could give their land to shareholder or other type of land tenure, by which they can enjoy the ownership of land, and in such a way tea farming can be sustainable in locality.

\section{DECLARATION OF CONFLICT OF INTERESTS}

The authors declare no conflict of interest. The founding sponsors had no role in the design of the study; in the collection, analyses, or interpretation of data; in the writing of the manuscript, and in the decision to publish the results.

\section{AUTHORS' CONTRIBUTIONS}

All authors contributed equally for the conception and writing of the manuscript. All authors critically revised the manuscript and approved of the final version.

\section{REFERENCES}

ABAY, C.; et al. An analysis of input use efficiency in tobacco production with respect to sustainability: The case study of Turkey. Journal of Sustainable Agriculture, v.24 n.3, p. 123-143, 2004. Available from: <https://doi.org/10.1300/J064v24n03_09>. Accessed: Mar. 20, 2018. doi: 10.1300/J064v24n03_09.

ABDUL-RAHMAN, A. Stochastic frontier analysis (SFA) of technical efficiency, insights from smallholder cotton farmers in the Northern Region of Ghana. Global Journal of Agricultural Economics, Extension and Rural Development, v.4, n.1, p.361$367,2016$.

AISYAH, N., Arumugam, N., Hussein, M. A., \& Latiff, I. Factors affecting the technical efficiency level of inshore fisheries in Kuala Terengganu; Malaysia. International Journal of Agriculture, Management, and Development. V. 2, p. 49-56, 2012: Available from: <http://dx.doi.org/10.22004/ag.econ.147578>. Accessed: Apr. 15, 2018. doi: 10.22004/ag.econ.147578.

Ciência Rural, v.49, n.12, 2019. 
ALAM, F. Measuring technical, allocative and cost efficiency of pangas (Pangasius hypophthalmus: Sauvage 1878) fish farmers of Bangladesh. Aquacult. Res., 42, 1487-1500. 2011: Available from: $\quad<$ https://doi.org/10.1111/j.1365-2109.2010.02741.x> Accessed: Apr. 12, 2018. doi. 10.1111/j.1365-2109.2010.02741.x.

ALEMDAR, T., et al. Cost and return analysis and technical efficiency of small-scale milk production: A case study for Cukurova region, Turkey. Journal of Animal and Veterinary Advances, v.9, n.4, p.744-847, 2010: Available from: <http:// dx.doi.org/10.3923/javaa.2010.844.847>. Accessed: Apr. 12, 2018. doi 10.3923/javaa.2010.844.847.

ATANASOVA TODOROVA, S.; LULCHEVA, D. Economic and social effects of land fragmentation on Bulgarian agriculture. Journal of Central European Agriculture, 6(4), 555-562. 2005: Available from: <https://hrcak.srce.hr/17322>. Accessed: Apr. 12, 2018.

AYLANGAN, P. (2011). Turkish Tea, Turkish Cultural Foundation. Turkish Cultural Foundation. Available from: <http://www. turkishculture.org/culinary-arts/turkish-tea-53.htm>. Accessed: May, 12, 2018.

BANKER, R.D., et al. Some models for estimating technical and scale inefficiencies in data envelopment analysis. Management Science, v.30, n.9, p.1078-1092. 1984: Available from: <https:// doi.org/10.1287/mnsc.30.9.1078>. Accessed Apr. 13, 2018.

BASNAYAKE, B. M. J. K.,; GUNARATNE, L. H. P. Estimation of technical efficiency and its determinants in the tea small holding sector in the Mid Country Wet Zone of Sri Lanka. Sri Lankan Journal of Agricultural Economics, v.4, n.1, p.137-150, 2011: Available from: <http://dx.doi.org/10.22004/ag.econ.205930>. Accessed: Apr. 13, 2018. doi: 10.22004/ag.econ.205930

BAYRAMOGLU, Z.; GUNDOGMUS, E. Cost efficiency of organic farming: a comparison between organic and conventional raisin-producing households in Turkey. Spanish Journal of Agricultural Research, v.6, n.1, p.3-11., 2008: Available from: $<\mathrm{http} / / / \mathrm{dx}$.doi.org/10.5424/sjar/2008061-289>. Accessed: Apr. 13, 2018. doi: 10.5424/sjar/2008061-289.

BEGUM, S.; et al. Socio-economic factors affecting food consumption pattern in rural area of district Nowshera, Pakistan. Sarhad J. Agric, 26(4), 649-653. 2010.

BHATT, M. S.; BHAT, S. A. Technical efficiency and farm size productivity-micro level evidence from Jammu \& Kashmir. International Journal of Food and Agricultural Economics, 2 (4), 27-49, 2014: Available from: <http://dx.doi.org/10.22004/ ag.econ.190809>. Accessed: Apr. 13, 2018. doi: 10.22004/ ag.econ.190809.

BOZ, I.; AKBAY, C. Factors influencing the adoption of maize in Kahramanmaras province of Turkey. Agricultural Economics, v.33, n.3, p.431-440, 2005: Available from: <https://doi.org/1 0.1111/j.1574-0864.2005.00305.x>. Accessed: Apr. 13, 2018. $10.1111 / \mathrm{j} .1574-0864.2005 .00305 . \mathrm{x}$

BOZ, I. Adoption of innovations and best management practices by goat farmers in eastern Mediterranean Region of Turkey. Journal of Agricultural Extension and Rural Development, v.7, n.7, p.229-239, 2015. Available from: <https://doi.org/10.5897/ JAERD2014.\%200668>. Accessed. Apr. 13, 2018: Doi: 10.5897/ JAERD2014. 0668.
BOZOĞLU, M.; CEYHAN, V. Energy conversion efficiency of trout and sea bass production in the Black Sea, Turkey. Energy, v.34, n.2, p.199-204, 2009: Available from: <https://doi. org/10.1016/j.energy.2008.12.001>. Accessed: Apr. 14, 2018. doi: 10.1016/j.energy.2008.12.001.

BOZOĞLU, M.; CEYHAN, V. Measuring the technical efficiency and exploring the inefficiency determinants of vegetable farms in Samsun province, Turkey. Agricultural Systems. 94, n.3, p.649-656, 2008: Available from: <https://doi.org/10.1016/j. agsy.2007.01.007>. Accessed: Apr. 14, 2018. doi: 10.1016/j. agsy.2007.01.007.

BRAVO-URETA, B.; et al. Technical efficiency in farming: A metaregression analysis. Journal of Productivity Analysis, 27: 57-72, 2007: Available from: <https://doi.org/10.1007/s11123-006-00253>. Accessed: Apr. 14, 2018. doi: 10.1007/s11123-006-0025-3.

CHARNES, A.; et al. Measuring the efficiency of decision-making units. European journal of operational research, v.2, n.6, p.429-444, 1978. Available from: <https://doi.org/10.1016/03772217(78)90138-8>. Accessed: Apr. 14, 2018. doi: 10.1016/03772217(78)90138-8

CINEMRE, H.; et al. The cost efficiency of trout farms in the Black Sea Region, Turkey. Aquaculture, 251, 324-332, 2006: Available from: $\quad<$ https://doi.org/10.1016/j.aquaculture.2005.06.016>. Accessed: Apr. 14, 2018. doi: 10.1016/j.aquaculture.2005.06.016.

COELLI, T. J.; et al. An introduction to efficiency and productivity analysis. Springer Science \& Business Media. United States of America. 2005.

COELLI, T.; et al; Technical, Allocative, Cost and Scale Efficiencies in Bangladesh Rice Cultivation: a Non-parametric Approach. Journal of Agricultural Economics, 53: 607-626, 2002: Available from: <https://doi.org/10.1111/j.1477-9552.2002. tb00040.x>. Accessed: Apr. 14, 2018. doi: 10.1111/j.14779552.2002.tb00040.x

DEININGER, K.; JIN, S. The potential of land rental markets in the process of economic development: Evidence from China. Journal of Development Economics, 78(1), 241-270. 2005: Available from: <https://doi.org/10.1016/j.jdeveco.2004.08.002>. Accessed: Apr. 14, 2018. doi: 10.1016/j.jdeveco.2004.08.002.

DEININGER, K.; et al. Moving off the farm: land institutions to facilitate structural transformation and agricultural productivity growth in China. World Development, v.59, p.505-520, 2014: Available from: $<$ https://doi.org/10.1016/j.worlddev.2013.10.009>. Accessed: Apr. 14, 2018. doi: 10.1016/j.worlddev.2013.10.009.

DEMIRCAN, V.; et al. Assessing the pure technical efficiency of dairy farms in Turkey. Agricultural Economics-Czech, v.56, n.3, p.141-148, 2010: Available from: <http://agriculturejournals.cz/ web/AGRICECON.htm>. Accessed: May, 01, 2018.

DESSALE, M.; Analysis of technical efficiency of small holder wheat-growing farmers of Jamma district, Ethiopia. Agriculture \& Food Security, 8(1), 1, 2019: Available from: < https://doi. org/10.1186/s40066-018-0250-9>. Accessed: May, 02, 2018. doi: 10.1186/s40066-018-0250-9.

FARRELL, M.J. The measurement of productive efficiency. Journal of the Royal Statistical Society. Series A (General), v.120, n.3, p.253-290, 1957: Available from: <https://doi.org/10.2307/2343100>. Accessed: May, 02 2018. doi. 10.2307/2343100. 
FENG, S. Land rental, off-farm employment and technical efficiency of farm households in Jiangxi Province, China. NJASWageningen Journal of Life Sciences, v.55, n.4, p.363-378, 2008: Available from: <https://doi.org/10.1016/S1573-5214(08)80026-7> Accessed: May, 02, 2018: doi: 10.1016/S1573-5214(08)80026-7.

GAFSI, M.; FAVREAU, J. L. Appropriate method to assess the sustainability of organic farming systems. In 9th European IFSA symposium, V. 47, 2010.

GHOSH, B. N.; et al. Elevation, slope aspect and integrated nutrient management effects on crop productivity and soil quality in North-west Himalayas, India. Journal of Mountain Science, 11(5), 1208-1217. 2014. Available from: <https://doi.org/10.1007/ s11629-013-2674-9>. Accessed: May, 04, 2018. doi: 10.1007/ s11629-013-2674-9.

GUJARATI, D. N. Basic econometrics. Mc-Graw: Hill Publishing Company New Delhi, 2003.

HANI, F.; et al. An Evaluation of Tea Farms in Southern India with the Sustainability Assessment Tool RISE. Symposium ID\# 1053. Swiss College of Agriculture (SCA), CH-3052 Zollikofen, University of Applied Sciences Bern, 2006.

HANSSON, H. How can farmer managerial capacity contribute to improved farm performance? A study of dairy farms in Sweden. Acta Agriculturae Scand Section C, 5(1), 44-61, 2008: Available from: <https://doi.org/10.1080/16507540802172808>. Accessed: May, 04, 2018. doi: 10.1080/16507540802172808.

HAQ, S. U.; Boz, I. Developing Sustainable Agriculture Indicators Framework for Tea Farms in Rize Province Turkey. International Conference On Food And Agricultural Economics. 27th -28 th April 2017 Alanya Alaaddin Keykubat University, Turkey. ISBN 978-605-65814-6-5, 2017.

HAQ, S. U.; et al. Exploring the determinants of technical inefficiency in mango enterprise: a case of Muzafargarh, Pakistan. Custose@gronegócio online, v.13(Apr/Jun), pp. 2018-236, 2017.

HAQ, U. S.; et al. Effect of Different Crop Management System on Technical Efficiency in Sugarcane Production in Faisalabad, Punjab Region of Pakistan. Journal of Biology, Agriculture and Healthcare. V.6, n.12, p. 103-114, 2016

HAZARIKA, C.; Subramanian, S. R. Estimation of technical efficiency in the stochastic frontier production function model: an application to the tea industry in Assam. Indian Journal of Agricultural Economics, v.54, n.2, 201-2011, 1999.

HELFAND, S. M.; Levine, E. S. Farm size and the determinants of productive efficiency in the Brazilian Center West. Agricultural Economics, v.31, n.23, p.241-249, 2004: Available from: < https:// doi.org/10.1111/j.1574-0862.2004.tb00261.x>. Accessed. May, 04, 2018. doi: 10.1111/j.1574-0862.2004.tb00261.x.

HONG, N. B.; YABE, M.. Technical Efficiency Analysis of Tea Production in the Northern Mountainous Region of Vietnam. Global Journal of Science Frontier Research: D Agriculture and Veterinary, v.15 n.1, p.30-42, 2015a.

HONG, N. B.; YABE, M.. Resource use efficiency of tea production in Vietnam: Using translog SFA model. Journal of Agricultural Science, v.7, n.9, p.160-172, 2015b: Available from: $<$ http://dx.doi.org/10.5539/jas.v7n9p160>. Accessed: May, 04, 2018. doi: $10.5539 /$ jas.v7n9p160
ILIYASU, A.; et al. Comparative analysis of technical efficiency for different production culture systems and species of freshwater aquaculture in Peninsular Malaysia. Aquaculture Reports, 3, 51-57, 2016: Available from: <https://doi.org/10.1016/j. aqrep.2015.12.001>. Accessed: May, 04, 2018. doi: 10.1016/j. aqrep.2015.12.001.

IRÁIZOZ, B.; et al. Assessing the technical efficiency of horticultural production in Navarra, Spain. Agricultural Systems, v.78, n.3, p.387-403, 2003: Available from: $<$ https://doi. org/10.1016/S0308-521X(03)00039-8>. Accessed: May, 04, 2018. doi: 10.1016/S0308-521X(03)00039-8.

JOLLANDS, N.; et al. Aggregate eco-efficiency indices for New Zealand-a principal components analysis. Journal of Environmental Management, 73(4), 293-305, 2004: Available from: $\quad<$ https://doi.org/10.1016/j.jenvman.2004.07.002>. Accessed: May, 04, 2018. doi: 10.1016/j.jenvman.2004.07.002.

KALANGI, L. S.; et al. Technical Efficiency of Beef Cattle Breeding Business in East Java Province. Media Peternakan, v.37, n.2, p.136-142, 2014: Available from: <https://doi.org/10.5398/ medpet.2014.37.2.136>. Accessed: May, 04, 2018. doi: 10.5398/ medpet.2014.37.2.136.

KALIBA, A.R.; et al. Efficiency change and technological progress in the US catfish-processing sector, 1986-2005. Aquacult. Econ. Manag, 11, 53-72, 2007: Available from: <https://doi. org/10.1080/13657300701202718>. Accessed: May, 04, 2018. doi $10.1080 / 13657300701202718$.

KARANI-GICHIMU, C.; et al. Factors Affecting Technical Efficiency of Passion Fruit Producers in the Kenya Highlands. Asian Journal of Agricultural Extension Economics and Sociology, v.5, n.3, p.126-136, 2015: Available from: <https:// doi.org/10.9734/AJAEES/2015/10629>. Accessed: May, 04, 2018. doi: 10.9734/AJAEES/2015/10629.

KHAN, N.; MUKHTAR, H. Tea and health: studies in humans. Current pharmaceutical design, v.19, n.34, p.6141-6147, 2013.

KILIC, O.; et al. Determinants of economic efficiency: A case study of hazelnut (Corylus avellana) farms in Samsun Province, Turkey. New Zealand Journal of Crop and Horticultural Science, v.37, n.3, p.263-270, 2009: Available from: $<$ https://doi org/10.1080/01140670909510272>. Accessed: May, 04, 2018. doi: $10.1080 / 01140670909510272$

KUMAR, S.; GULATI, R. An examination of technical, pure technical, and scale efficiencies in Indian public sector banks using data envelopment analysis. Eurasian Journal of Business and Economics, v.1, n.2, p.33-69, 2008.

KYEI, L.; et al. Analysis of factors affecting the technical efficiency of cocoa farmers in the Offinso district-Ashanti region, Ghana. American journal of social and management sciences, 2(2), 208-216. 2011: Accessed: May, 04, 2018. doi: 10.5251/ ajsms.2011.2.2.208.216

LAMBARRAA, F; et al. Technical efficiency analysis and decomposition of productivity growth of Spanish olive farms. Spanish Journal of Agricultural Research, 5(3), 259-270. 2006:Available from: <http://dx.doi.org/10.5424/sjar/2007053247>. Accessed: May, 04, 2018: doi: 10.5424/sjar/2007053-247.

LI, M.; SICULAR, T. Aging of the labor force and technical efficiency in crop production: Evidence from Liaoning province, China. China

Ciência Rural, v.49, n.12, 2019. 
Agricultural Economic Review, 5(3), 342-359. 2013: Available from: $<$ https://doi.org/10.1108/CAER-01-2012-0001>. Accessed: May, 04, 2018. doi: 10.1108/CAER-01-2012-0001.

LONG, J. S. Regression models for categorical and limited dependent variables. advanced quantitative techniques in the social sciences number 7. Sage Publications, 1997.

MIKA A.; et al. Relationship between fruit distribution within Jonagold' apple canopy, fruit quality and illumination. J. FRUIT. ORNAM. PLANT RES.,10: 75-84, 2002.

NYAGAKA, D. O.; et al. Technical efficiency in resource use evidence from smallholder Irish potato farmers in nyandarua north district, kenya. African Journal of Agricultural Research, 5(11), 1179-1186, 2010: Available from: < https://doi.org/10.5897/ AJAR09.296>. Accessed: May, 05, 2018. doi: 10.5897/ AJAR09.296.

O'BRIEN, R. M. A caution regarding rules of thumb for variance inflation factors. Quality \& quantity, 41(5), 673-690, 2007: Available from: <https://doi.org/10.1007/s11135-006-9018-6>. Accessed: May, 04, 2018. doi: 10.1007/s11135-006-9018-6.

ÖZCAN, M.; YAZICIOĞLU, E. Türkiye çay yetiştiriciliğinin sorunları ve öncelikleri. II. Rize Kalkınma Sempozyumu Çay Lojistik - Turizm Rize, 3 - 4 Mayıs 2013. Bildiriler Kitabı, 2013.

PAN, Y.; JACKSON, R. T. Ethnic difference in the relationship between acute inflammation and serum ferritin in US adult males. Epidemiology \& Infection, 136(3), 421-431, 2008: Available from: <https://doi.org/10.1017/S095026880700831X>. Accessed: May, 05, 2018. doi: 10.1017/S095026880700831X.

PLACE, F.; OTSUKA, K. Land tenure systems and their impacts on agricultural investments and productivity in Uganda. Journal of Development Studies, 38(6), 105-128, 2002: Available from: $<$ https://doi.org/10.1080/00220380412331322601>. Accessed: May, 05, 2018. doi: 10.1080/00220380412331322601.

POUNGCHOMPU, S.; CHANTANOP, S. Factor affecting technical efficiency of smallholder rubber Farming in Northeast Thailand. American Journal of Agricultural and Biological Sciences, 10(2), 83, 2015: Available from: <https://doi/ org/10.3844/ajabssp.2015.83.90>. Accessed: May, 05, 2018. doi: 10.3844/ajabssp.2015.83.90.

RTB. Rize Ticaret Borsasi, Doğu Karadeniz Bölgesi Tarim Ürünleri Raporu. Accessed on: 07/15/2017 Available from: <http:// www.rtb.org.tr/icerik/bolgesel-arastirma-ve-raporlar, 2014>.

SAIGENJI, Y.; ZELLER, M.. Effect of contract farming on productivity and income of small holders: The case of tea production in north-western Vietnam. In Contributed Paper prepared for presentation at the International Association of Agricultural Economists Conference, Beijing, China, p. 16-22, 2009.

SAKLI, A. R. A critical review of recent sectoral structure proposal for Turkish tea sector. Humanity \& Social Science Journal. v 6 , p.01-07, 2011

SARAFIDIS, V. An assessment of comparative efficiency measurement techniques. Europe Economics, v.16, p. 01-21, 2002.

SIDDIQUE, F. Effectiveness and Efficiency - Why are They Important to a Business Entity? Download From <https://www. linkedin.com/pulse/20140829162438-59817714-effectivenessand-efficiency-why-are-they-important-to-a-business-entity>. Accessed: Aug. 21, 2017, 2014.

SOULE, M. J.; et al. Land tenure and the adoption of conservation practices. American journal of agricultural economics, 82(4), 993-1005, 2000: Available from: <https://doi.org/10.1111/00029092.00097>. Accessed: May, 05, 2018. doi: 10.1111/00029092.00097 .

TREDER, W.; et al. Relations between tree age, fruit load and mean fruit weight. Journal of Fruit and Ornamental Plant Research, 18(2), 139-149. 2010

TZOUVELEKAS, V; ; et al. Technical efficiency of alternative farming systems: the case of Greek organic and conventional olivegrowing farms. Food Policy, v.26, n.6, p.549-569. 2001: Available from: $\quad<$ https://doi.org/10.1016/S0306-9192(01)00007-0>. Accessed: May, 05, 2018. doi: 10.1016/S0306-9192(01)00007-0.

UL HAQ, S.; BOZ, I. Developing a set of indicators to measure sustainability of tea cultivating farms in Rize Province, Turkey. Ecological Indicators, v.95, p.219-232, 2018: Available from: $<$ https://doi.org/10.1016/j.ecolind.2018.07.041>. Accessed: May, 06, 2018. doi: 10.1016/j.ecolind.2018.07.041.

UL HAQ, S.; BOZ, I. Measuring environmental, economic, and social sustainability index of tea farms in Rize Province, Turkey. Environment, Development and Sustainability, 1-23. 2019: Available from: $<$ https://doi.org/10.1007/s10668-019-00310-x $>$. Accessed: May, 05, 2018. doi: 10.1007/s10668-019-00310-x.

WANG, H.; Riedinger, J.; Jin, S. Land documents, tenure security, and land rental development: Panel evidence from China. China Economic Review, v.36, p.220-235, 2015. Available from: $<$ https://doi.org/10.1016/j.chieco.2015.09.005>. Accessed: May, 04, 2018. doi: 10.1016/j.chieco.2015.09.005.

WORLD ATLAS. The world's top ten tea producing nations Economics. Downloaded on 15/16/2016. Available from: <http:// www.worldatlas.com/articles/the-worlds-top-10-tea-producingnations.html>, 2016

YAMANE, T. Temel Örnekleme Yöntemleri. Çevirenler: Alptekin Esin, Celal Aydın, M. Akif Bakır, Esen Gürbüzsel. Literatür Yayınc1lık, İstanbul, 2001.

YAO, Y. The Chinese land tenure system: Practice and perspectives. The Dragon and the Elephant: Agricultural and Rural Reforms in China and India. Johns Hopkins University Press, Baltimore, Maryland, p.49-70, 2007.

ZAHM, F.; et al. Assessing farm sustainability with the IDEA method-from the concept of agricultural sustainability to case studies on farms. Sustainable development, v.6, n.4, p.271-281, 2008: Available from: $<$ https://doi.org/10.1002/sd.380 $>$. Accessed: May, 04, 2018. doi: 10.1002/sd.380.

ZHANG, Y.; et al. The impact of land reallocation on technical efficiency: evidence from China. Agricultural Economics, v.42, n.4, p.495-507, 2011: Available from: <https://doi.org/10.111 1/j.1574-0862.2010.00532.x>. Accessed: May, 04, 2018. doi: 10.1111/j.1574-0862.2010.00532.x. 